\title{
Cellulase degradation of whole rice straw
}

\author{
J. Vadiveloo \\ Faculty of Applied Sciences, MARA University of Technology \\ 40450 Shah Alam, Malaysia
}

(Received 6 May 1999; accepted 13 January 2000)

\begin{abstract}
The dry matter degradation in a cellulase-buffer solution of the whole straw of six Malaysian rice varieties was estimated before and after treatment for 2 ] days in a $4 \%$ urea or $4 \%$ sodium hydroxide $(\mathrm{NaOH})$ solution. Degradation characteristics were estimated from the equation $\mathrm{p}=\mathrm{a}+\mathrm{b}\left(1-\mathrm{e}^{-\mathrm{ct}}\right)$. Both urea and $\mathrm{NaOH}$ treatment significantly increased the rapidly degradable (constant a) and slowly degradable (constant b) fractions. The degradation rate (constant c) was significantly reduced by urea treatment but not by $\mathrm{NaOH}$ treatment. The degradation constants were independent of the agronomic and morphological characteristics of the untreated straws.
\end{abstract}

KEY WORDS: degradation, rice straw, urea treatment, $\mathrm{NaOH}$ treatment

\section{INTRODUCTION}

The rumen dry matter degradation of feeds has been conventionally carried out using the in situ nylon bag (Mehrez and Ørskov, 1977) or the in vitro gas production technique (Menke and Steingass, 1988; Blummel and Ørskov, 1993). Both of these are regarded as being unsuitable for routine use due to the requirement for fistulated animals, the tediousness of extracting rumen liquor and the high degree of standardisation expected before comparisons can be made (Bughrara et al., 1992; Lopez et al., 1998). In the case of the nylon bag procedure, variation in bag size, pore size, substrate particle size, variation in animal diet, particle loss and variation in the microbial population inside and outside the bag are factors which contribute to the low reproducibility of the results (Carro et al., 1994; Pike et al., 1996; Madsen et al., 1997). Variation in the quality of fresh inoculum and the non-adaptation of the rumen inoculum to test feeds have been cited as contributing to the low reproducibility of results from the gas production technique (Prasad et al., 1994). 
The conventional method of improving the feeding value of rice straw and other cereal crop residues is through physical and chemical treatment. Lignocelluloses from monocotyledonous crops such as cereal straws respond well to chemical treatment because the action is hydrolysable in nature. Sodium hydroxide and urea treatment of Malaysian rice straw varieties improved the chemical composition and in vitro dry matter digestibility of the straw (Vadiveloo, 1996) and increased its voluntary intake and digestibility by goats (Vadiveloo, 1986, 1989; Tuen et al., 1991). These results complement other studies on urea-treated rice straw which have recorded improvements in nitrogen content, dry matter degradability and dry matter intake (Mgheni et al., 1993; Shen et al., 1998 a,b).

Enzymatic procedures using cellulase have rarely been employed to study the characteristics of degradation although they have been proposed for the routine estimation of end-point digestion (Bughrara and Sleper, 1986). As a technique for the latter, it is cheap, fast and sufficiently precise (Carro et al., 1994; Magai et al., 1994; Givens et al., 1995) although insensitive to factors such as associative effects and toxins (Prasad et al., 1994).

Studies on the nutritive value of Malaysian rice straw varieties have employed cellulase to estimate end-point digestion (Vadiveloo, 1992, 1995). As the degradation characteristics of Malaysian rice straw varieties have not been documented, the present study was initiated.

\section{MATERIAL AND METHODS}

\section{Rice straw}

Six straw varieties, MR 84, MR 151, MR 162, MR 164, MR 166 and MR 167 hand-harvested $12 \mathrm{~cm}$ above the ground in June 1994 from the Tanjung Karang district of Selangor were field-dried. The relative proportion by weight of leaf blade, leaf sheath and stem (including inflorescence) in approximately $500 \mathrm{~g}$ of whole straw was estimated in triplicate for each variety. Whole straw was ground to pass through a $1 \mathrm{~mm}$ sieve and treated with $4 \%$ urea or $4 \%$ sodium hydroxide solution in the ratio of $50 \mathrm{~g}$ straw to $200 \mathrm{ml}$ of solution. The treated samples were kept in screw-top plastic jars at $27^{\circ} \mathrm{C}$ for 21 days after which they were oven dried at $60^{\circ} \mathrm{C}$ to constant weight.

\section{Chemical composition and degradability}

Treated and untreated straw varieties were analysed for total ash and crude protein (AOAC, 1984), neutral detergent fibre and ash insoluble in neutral deter- 
gent solution (Van Soest et al., 1991). In vitro dry matter digestibility (IVD) was estimated by the cellulase-neutral detergent solution procedure of Bughrara and Sleper (1986) using the Onozuka 3S enzyme (Yakult Biochemicals). For the estimation of cellulase dry matter degradability, $0.5 \mathrm{~g}$ samples of whole straw were incubated in a cellulase-buffer solution $(25 \mathrm{~g}$ cellulase in $1000 \mathrm{ml}$ of $0.05 \mathrm{M}$ sodium acetate/glacial acetic acid, $\mathrm{pH} 4.6$ ) for $3,6,12,24,48$ and $72 \mathrm{~h}$ at $38^{\circ} \mathrm{C}$. After incubation, the residues were completely recovered by filtering in a Tecator Fibertec System, washed with water, oven-dried at $100^{\circ} \mathrm{C}$ and weighed. Degradation characteristics were described by the exponential equation $\mathrm{p}=\mathrm{a}+\mathrm{b}\left(1-\mathrm{e}^{-\mathrm{ct}}\right)$ where $\mathrm{p}$ is degradation at time $\mathrm{t}$ (hours) and $\mathrm{a}, \mathrm{b}$ and $\mathrm{c}$ are constants (\%) representing the rapidly degradable fraction, slowly degradable fraction and degradation rate, respectively (Ørskov and McDonald, 1979).

\section{Statistical analyses}

Straw varieties were compared for differences in their proportions of leaf blade, leaf sheath and stem by Kruskal-Wallis non-parametric analysis of variance. Within treatments, differences between varieties in chemical composition, IVD and cellulase dry matter degradation were compared by a one-way analysis of variance. Due to the absence of replication within varieties, differences in degradation characteristics between varieties could not be compared by an analysis of variance. Instead, the method of principal components was used.

Principal components is one of several multivariate statistical procedures wherein several criterion variables can be used simultaneously to evaluate mean differences. In principal components analysis, linear combinations of the criterion variables are computed, the number of linear combinations computed being equal to the number of criterion variables. The first combination or first principal component accounts for the largest variance. The criterion variables in each component can be summarised in a principal component score, which on the basis of its sign and magnitude, can be used to rank the means. The degradation constants ( $a, b$ and $c$ ) were used as criterion variables and varieties were compared for their scores on the first principal component.

The mean effect of treatment on chemical composition, IVD, cellulase dry matter degradation and degradation characteristics were compared by a one-way analysis of variance with six replicates (varieties) per treatment. For each treatment, simple correlations between the degradation constants and the morphology, agronomy and chemical composition of the varieties were also calculated.

All statistical analyses were run on a SAS Version 6 statistical package (Statistical Analysis Systems Institute Inc., 1987). 


\section{RESULTS}

The agronomic and morphological characteristics of the six varieties are shown in Table 1. Varieties differed significantly $(\mathrm{P}<0.05)$ in the percentage of leaf blade and leaf sheath only.

TABLE 1

Agronomic and morphological characteristics of the straw varieties

\begin{tabular}{lccccrr}
\hline Variable & \multicolumn{7}{c}{ Variety } \\
\cline { 2 - 7 } & MR162 & MR166 & MR151 & MR84 & MR167 & MR164 \\
\hline Culm height, cm & 69 & 79 & 84 & 81 & 79 & 75 \\
Maturity, days & 116 & 117 & 138 & 124 & 121 & 117 \\
Yield. kg/ha & 4262 & 4340 & 5063 & 4687 & 4065 & 3875 \\
Leaf blade, \% & 31.4 & 28.0 & 34.2 & 31.6 & 29.6 & 31.5 \\
Leaf sheath, \% & 41.1 & 41.2 & 37.6 & 38.8 & 42.0 & 41.0 \\
Stem, \% & 26.2 & 29.7 & 27.6 & 28.9 & 28.2 & 26.3 \\
\hline
\end{tabular}

Varietal differences in chemical composition and IVD before and after treatment were significant $(\mathrm{P}<0.001)$ but small in magnitude and hence are not reported. Varietal differences in cellulase dry matter degradation show that differences were generally more pronounced following chemical treatment (Table 2).

The degradation characteristics of each variety are shown in Table 3. Principal component analysis of the degradation constants showed that the first principal component accounted for 73,60 and $70 \%$, respectively, of the variance in the untreated, urea and $\mathrm{NaOH}$ data. Principal component scores were ranked in sign and magnitude, the highest negative score being ranked first. A large response to urea or $\mathrm{NaOH}$ treatment would be reflected in a change in the sign and magnitude of the component score. Compared to untreated straw, urea or $\mathrm{NaOH}$ treatment did not consistently alter the ranking of the straw varieties - MR 84 which was lowest ranked before treatment was second ranked after urea treatment but remained lowest ranked after $\mathrm{NaOH}$ treatment; MR 164 retained its ranking after urea treatment but was highest ranked after $\mathrm{NaOH}$ treatment.

The mean effects of urea and $\mathrm{NaOH}$ treatment are shown in Table 4. Both treatments increased IVD and ash content but reduced NDF content. Urea treatment also increased CP content. Dry matter degradation increased significantly for all incubation times $(\mathrm{P}<0.001)$. Urea and $\mathrm{NaOH}$ treatments significantly increased the rapidly degradable (constant $a$ ), slowly degradable (constant $b$ ) and potentially degradable $(a+b)$ fractions $(P<0.001)$. The rate of dry matter degradation (constant $\mathrm{c}$ ) was significantly reduced after urea treatment $(\mathrm{P}<0.05)$ but not after $\mathrm{NaOH}$ treatment $(\mathrm{P}>0.05)$. 
TABLE 2

Effect of time of incubation on cellulase dry matter degradation, \%

\begin{tabular}{llllllll}
\hline Treatment & Variety & \multicolumn{5}{c}{ Time of incubation, h } \\
\cline { 3 - 7 } Untreated & & \multicolumn{7}{c}{3} & 6 & 12 & 24 & 48 & 72 \\
& MR162 & 20.5 & 24.4 & 26.8 & 30.3 & 32.4 & 33.9 \\
& MR166 & 19.6 & 23.6 & 26.4 & 30.3 & 30.6 & 30.3 \\
& MR151 & 19.4 & 22.8 & 26.8 & 30.7 & 31.2 & 34.5 \\
& MR84 & 19.0 & 21.7 & 26.8 & 29.7 & 30.2 & 29.4 \\
& MR167 & 20.1 & 23.9 & 27.5 & 30.5 & 34.9 & 31.8 \\
& MR164 & 20.0 & 22.9 & 28.0 & 30.6 & 30.9 & 32.0 \\
& SE diff ${ }^{+}$ & $0.41 \mathrm{~ns}$ & $0.63 \mathrm{~ns}$ & $0.51 \mathrm{~ns}$ & $0.44 \mathrm{~ns}$ & $0.64^{* *}$ & $0.47^{* * *}$ \\
& & & & & & \\
& MR162 & 26.3 & 32.1 & 35.0 & 41.5 & 44.7 & 46.3 \\
& MR166 & 25.4 & 31.7 & 35.4 & 41.6 & 44.8 & 46.0 \\
& MR151 & 24.3 & 30.3 & 33.7 & 39.4 & 42.8 & 44.0 \\
& MR84 & 26.7 & 32.5 & 36.5 & 41.6 & 45.5 & 46.5 \\
& MR167 & 25.0 & 30.3 & 35.0 & 40.1 & 43.0 & 45.0 \\
& MR164 & 24.5 & 30.8 & 34.6 & 40.7 & 43.4 & 46.3 \\
& SE diff ${ }^{+}$ & $0.74 \mathrm{~ns}$ & $0.42^{* *}$ & $0.47^{* *}$ & $0.91 \mathrm{~ns}$ & $0.77 \mathrm{~ns}$ & $0.46^{* * *}$ \\
& MR162 & 42.7 & 50.1 & 57.6 & 61.9 & 65.7 & 66.9 \\
& MR166 & 43.9 & 50.6 & 59.7 & 63.3 & 67.4 & 69.4 \\
& MR151 & 43.9 & 50.7 & 58.7 & 62.5 & 65.5 & 66.6 \\
& MR84 & 42.7 & 50.9 & 59.0 & 63.2 & 67.3 & 67.8 \\
& MR167 & 41.4 & 48.7 & 57.1 & 59.7 & 65.1 & 68.2 \\
& MR164 & 40.2 & 50.8 & 55.8 & 60.1 & 65.8 & 69.5 \\
& SE diff ${ }^{+}$ & $0.62 * *$ & $0.85 \mathrm{~ns}$ & $0.35 * * *$ & $0.41 * * *$ & $0.26 * * *$ & $0.74 *$ \\
\hline
\end{tabular}

*** $\mathrm{P}<0.001,{ }^{* *} \mathrm{P}<0.01,{ }^{*} \mathrm{P}<0.05$, ns $\mathrm{P}>0.05$

+ $\mathrm{SE}$ of the difference between two means

Significant correlations $(\mathrm{P}<0.05)$ were obtained between the following pairs of variables:

Untreated : potentially degradable fraction and insoluble ash content, $\mathrm{r}=0.82$

Urea-treated : degradation rate and stem percentage, $r=0.89$

rapidly degradable fraction and IVD, $\mathrm{r}=0.85$

$\mathrm{NaOH}$-treated : degradation rate and grain yield, $\mathrm{r}=0.91$

degradation rate and IVD, $r=0.84$.

\section{DISCUSSION}

The morphological composition of the present six varieties was similar to the varieties reported by Vadiveloo (1992) but varied from the varieties reported by Vadiveloo (1995) being higher in leaf content. 
TABLE 3

Degradation constants and statistics on the first principal component

\begin{tabular}{|c|c|c|c|c|c|c|c|c|}
\hline \multirow[t]{2}{*}{ Treatment } & \multirow[t]{2}{*}{ Variety } & \multicolumn{5}{|c|}{ Constants } & \multicolumn{2}{|c|}{ Statistics } \\
\hline & & a, $\%$ & b. \% & $\mathrm{c}, / \mathrm{hr}$ & $a+b$ & $\mathrm{RSD}^{+}$ & score & rank \\
\hline \multirow[t]{6}{*}{ Untreated } & MR 162 & 18.3 & 15.2 & 0.0691 & 33.5 & 0.77 & -1.68 & 1 \\
\hline & MR 166 & 14.9 & 15.7 & 0.1234 & 30.6 & 0.51 & 0.22 & 4 \\
\hline & MR 15I & 16.0 & 17.2 & 0.0801 & 33.2 & 1.04 & -0.22 & 3 \\
\hline & MR84 & 13.1 & 16.9 & 0.1319 & 30.0 & 0.80 & 1.24 & 6 \\
\hline & MR167 & 16.3 & 16.9 & 0.0906 & 33.2 & 1.25 & -0.23 & 2 \\
\hline & MR164 & 14.6 & 16.9 & 0.1214 & 31.5 & 0.76 & 0.69 & 5 \\
\hline \multirow[t]{6}{*}{ Urea } & MR 162 & 22.9 & 23.1 & 0.0670 & 46.0 & 1.24 & -1.57 & 1 \\
\hline & MR 166 & 21.2 & 24.5 & 0.0769 & 45.7 & 1.00 & 1.16 & 6 \\
\hline & MR151 & 20.7 & 23.1 & 0.0723 & 43.8 & 0.94 & 0.02 & 3 \\
\hline & MR84 & 22.9 & 23.3 & 0.0731 & 46.2 & 0.88 & -0.74 & 2 \\
\hline & MR167 & 20.9 & 23.4 & 0.0756 & 44.3 & 0.88 & 0.49 & 4 \\
\hline & MR164 & 20.8 & 24.6 & 0.0703 & 45.4 & 1.28 & 0.63 & 5 \\
\hline \multirow[t]{6}{*}{$\mathrm{NaOH}$} & MR 162 & 35.1 & 31.0 & 0.1032 & 66.1 & 1.14 & 0.02 & 4 \\
\hline & MR166 & 36.0 & 32.1 & 0.1002 & 68.1 & 1.35 & -0.11 & 3 \\
\hline & MR151 & 35.3 & 30.5 & 0.1148 & 65.8 & 0.94 & 0.04 & 5 \\
\hline & MR84 & 33.5 & 33.6 & 0.1142 & 67.1 & 1.11 & 1.83 & 6 \\
\hline & MRl67 & 35.6 & 30.9 & 0.0839 & 66.5 & 1.97 & -0.70 & 2 \\
\hline & MR 164 & 36.3 & 31.4 & 0.0748 & 67.7 & 2.51 & -1.07 & 1 \\
\hline
\end{tabular}

${ }^{+}$residual standard deviation

The absolute values for constant $a$ and constant $b$ for untreated straw (Tables 3 and 4) were lower than similar values obtained by the nylon bag or gas production techniques (Walli et al., 1988; Nakashima and Ørskov, 1990; Shen et al., 1998 b) probably because cellulase dry matter degradation only mimics part of the complex process taking place in the rumen (Lopez et al., 1998). The increase in potential dry matter degradability of rice straw after urea or $\mathrm{NaOH}$ treatment was in accordance with the findings of Nakashima and Ørskov (1990) and Walli et al. (1988) with ammonia-treated rice straw. In the case of urea-treated straw, this may be attributed to an increased extraction of biogenic silica (Shen et al., 1998a). With wheat straw, the improvement in dry matter degradability after ammonia treatment is attributed to an increased solubilisation of lignin (Kondo et al., 1992).

The rate of dry matter degradation (constant $\mathrm{c}$ ) was significantly reduced after urea treatment $(\mathrm{P}<0.05)$, but not significantly altered following $\mathrm{NaOH}$ treatment $(\mathrm{P}>0.05$; Table 4$)$. These effects may be explained by the different response of the leaf and stem fractions to urea and $\mathrm{NaOH}$ treatment observed by 
Vadiveloo (1999). Urea treatment resulted in a significant reduction in the degradation rate of the stem fraction but did not result in a significant change in the degradation rates of the leaf blade and leaf sheath fractions. With $\mathrm{NaOH}$ treatment however, degradation rate was significantly reduced in the stem and leaf sheath fractions but was significantly increased in the leaf blade fraction.

Chemical treatment did not consistently affect the ranking of straw varieties based on their degradation characteristics (Table 3). With temperate cereal straws, the potential degradability after ammonia or urea treatment is greater for straw varieties of initially lower degradability (Tuah et al., 1986; Goto et al., 1991; Colucci et al., 1992). However the response to $\mathrm{NaOH}$ treatment of wheat, barley and oat straw varieties was independent of initial digestibility (Moss et al., 1990).

Insoluble ash (mainly silica) content and potential dry matter degradability in the untreated straw was significantly correlated $(\mathrm{r}=0.82 ; \mathrm{P}<0.05)$ but since the range of the two variables was narrow (standard deviation $=0.84$ and 1.49 , respectively) the significance may be, for now at least, empirical only. It is interesting to note however that Nakashima and Ørskov (1990) also reported a significant correlation $(\mathrm{r}=0.91 ; \mathrm{P}<0.01)$ between silica and potential degradabi-

TABLE 4

Treatment effects on chemical composition (\% in DM), cellulase dry matter degradation (\%) and degradation constants

\begin{tabular}{llcccc}
\hline Parameter & Variable & Untreated & Urea & NaOH & SE diff ${ }^{*}$ \\
\hline Chemical composition & Total ash & 17.8 & 19.5 & 22.6 & $0.27^{* * *}$ \\
& NDF & 63.5 & 62.3 & 54.6 & $0.49^{* * *}$ \\
& Insoluble ash & 5.3 & 9.1 & 10.0 & $0.40^{* * *}$ \\
& IVD & 54.0 & 62.0 & 86.4 & $0.41^{* * *}$ \\
& CP & 3.3 & 5.0 & 2.8 & $0.16^{* * *}$ \\
Time of incubation, h & 3 & & & & \\
& 6 & 19.7 & 25.3 & 42.4 & $0.45^{* * *}$ \\
& 12 & 23.2 & 31.3 & 50.3 & $0.41^{* * *}$ \\
& 24 & 27.0 & 35.0 & 58.0 & $0.42^{* * *}$ \\
& 48 & 30.3 & 40.8 & 61.8 & $0.45^{* * *}$ \\
& 72 & 31.7 & 44.0 & 66.1 & $0.54^{* * *}$ \\
& & 32.0 & 45.7 & 68.1 & $0.59^{* * *}$ \\
Degradation constants & a, \% & 15.6 & 21.6 & 35.2 & $0.76^{* * *}$ \\
& b, \% & 16.3 & 23.7 & 31.5 & $0.52^{* * *}$ \\
& $\mathrm{c}, \mathrm{hr}^{-1}$ & 0.1019 & 0.0725 & 0.0990 & $0.01032^{*}$ \\
& $\mathrm{a}+\mathrm{b}, \%$ & 32.0 & 45.2 & 66.9 & $0.67^{* * *}$ \\
& $\mathrm{RSD}{ }^{++}$ & 1.18 & 1.27 & 1.75 & \\
\hline
\end{tabular}

+ SE of the difference between two means

${ }^{++}$residual standard deviation 
lity in rice straw. The degradation constants of the untreated straw varieties were not significantly correlated to their agronomic or morphological characteristics suggesting that both sets of characteristics may be jointly selected in rice breeding programmes (Vadiveloo, 1995).

\section{ACKNOWLEDGEMENTS}

Technical assistance by Nik Nazri Nik Yusof, Ku Aishah Ku Din and Astifarini Buang is recorded with thanks. Financial assistance was provided by the MARA University of Technology. Rice straw was provided by the Malaysian Agricultural Research and Development Institute, Tanjung Karang.

\section{REFERENCES}

Association of Official Analytical Chemists, 1984. Official Methods of Analysis. 14th Edition. Washington, DC

Blummel M., Ørskov E.R., 1993. Comparison of in vitro gas production and nylon-bag degradability of roughage in predicting feed intake in cattle. Anim. Feed. Sci. Tech. 40, 109-119

Bughrara S.S., Sleper D.A., 1986. Digestion of several temperate forage species by a prepared cellulase solution. Agron. J. 78, 94-98

Bughrara S.S., Sleper D.A., Beuselinck P.R., 1992. Comparison of cellulase solutions for use in digesting forage samples. Agron. J. 84, 631-636

Carro M.D., Lopez S., Gonzalez J.S., Ovejero F.J., 1994. Comparison of laboratory methods for predicting digestibility of hay in sheep. Small Ruminant Res. 14, 9-17

Colucci P.E., Falk D., Macleod G.K., Gricve D.G., 1992. In situ organic matter degradability of untreated and urea-treated varieties of spring barley and oat straws, and of untreated varieties of winter wheat straws. Anim. Feed Sci. Tech. 37, 73-84

Givens D.I., Cottyn B.G., Dewey P.J.S., Steg A., 1995. A comparison of the neutral detergentcellulase method with other laboratory methods for predicting the digestibility in vivo of maize silages from three European countries. Anim. Feed Sci. Tech. 54, 55-64

Goto M., Gordon A.H., Chesson A., 1991. Effect of gaseous ammonia on barley straws showing different rumen degradabilities. J. Sci. Food Agr. 56, 141-153

Kondo T., Ohshita T., Kyuma T., 1992. Comparison of characteristics of soluble lignins from untreated and ammonia-treated wheat straw. Anim. Feed Sci. Tech. 39, 253-263

Lopez S., Carro M.D., Gonzalez J.S., Ovejero F.J., 1998. Comparison of different in vitro and in situ methods to estimate the extent and rate of degradation of hays in the rumen. Anim. Feed Sci. Tech. 73, 99-113

Madsen J., Hvelplund T., Weisbjerg M.R., 1997. Appropriate methods for the evaluation of tropical feeds for ruminants. Anim. Feed Sci. Tech. 69, 53-66

Magai M.M., Sleper D.A., Beuselinck P.R., 1994. Degradation of three warm-season grasses in a prepared cellulase solution. Agron. J. 86, 1049-1053 
Mehrez A.Z., Ørskov E.R., 1977. A study of the artificial bag technique for determining the digestibility of feeds in the rumen. J. Agr. Sci. 88, 645-650

Menke K.H., Steingass H., 1988. Estimation of the energetic feed value obtained from chemical analysis and in vitro gas production using rumen fluid. Anim. Res. Develop. 28, 7-55

Mgheni D.M., Kimambo A.E., Sundstøl F., Madsen J., 1993. Influence of urea treatment or supplementation on degradation, intake and growth performance of goats fed rice straw diets. Anim. Feed Sci. Tech. 44, 209-220

Moss A.R., Givens D.I., Everington J.M., 1990. The effect of sodium hydroxide treatment on the chemical composition, digestibility and digestible energy content of wheat, barley and oat straws. Anim. Feed Sci. Tech. 29, 73-87

Nakashima Y., Ørskov E.R., 1990. Rumen degradation of straw. 9. Effect of cellulase and ammonia treatment on different varieties of rice straws and their botanical fractions. Anim. Prod. 50, 309-317

$\emptyset$ rskov E.R., McDonald I., 1979. The estimation of protein degradability in the rumen from incubation measurements weighted according to rate of passage. J. Agr. Sci. 92, 499-503

Pike D.J., Owen E., Said A.N., 1996. The dacron bag technique for comparing rumen degradability of untreated and ammonia-treated barley straw - effect of particle size and degree of replication. J. Agr. Sci. 126, 201-205

Prasad C.S., Wood C.D., Sampath K.T., 1994. Use of in-vitro gas production to evaluate rumen fermentation of untreated and urea treated finger millet straw (Eleusine coracana) supplemented with different levels of concentrate. J. Sci. Food Agr. 65, 457-464

Shen H.Sh., Ni D.B., Sundst $\varnothing$ l F., 1998a. Studies on untreated and urea-treated rice straw from three cultivation seasons. 1. Physical and chemical measurements in straw and straw fractions. Anim. Feed Sci. Tech. 73, 243-261

Shen H.Sh., Sundst $\varnothing$ F., Ni D.B., 1998b. Studies on untreated and urea-treated rice straw from three cultivation seasons. 2. Evaluation of straw quality through in vitro gas production and in sacco degradation measurements. Anim. Feed Sci. Tech. 74, 193-212

Statistical Analysis Systems Institute Inc., 1987. SAS Users Guide : Statistics (version 6). Statistical Analysis Systems Institute Inc., Cary, NC

Tuah A.K., Lufadeju E., Ørskov E.R., Blackett G.A., 1986. Rumen degradation of straw. 1. Untreated and ammonia-treated barley, oat and wheat straw varieties and triticale straw. Anim. Prod. 43, 261-269

Vadiveloo, J., 1986. The effect of alkali treatment of straw and dried palm-oil sludge on the intake and performance of goats of varying genotype. Agr. Wastes 18, 233-245

Vadiveloo J., 1989. Supplementation of alkali-treated straw. Biol. Wastes 27, 153-157

Vadiveloo J., 1992. Varietal differences in the chemical composition and in vitro digestibility of rice straw. J. Agr. Sci. 119, 27-33

Vadiveloo J., 1995. Factors contributing to varietal differences in the nutritive value of rice straw. Anim. Feed Sci. Tech. 54, 45-53

Vadiveloo J., 1996. The use of multivariate statistics to evaluate the response of rice straw varieties to chemical treatment. Asian-Aust. J. Anim. Sci. 9, 83-89

Vadiveloo J., 1999. Nutritional properties of the leaf and stem of rice straw. Anim. Feed Sci. Tech. (in the press)

Van Soest. P.J., Robertson, J.B., Lewis, B.A., 1991. Method for dietary fiber, neutral detergent fiber and non-starch polysaccharides in relation to animal nutrition. J. Dairy. Sci. 74, 3583-3597

Walli T.K., Ørskov E.R., Bhargava P.K., 1988. Rumen degradation of straw. 3. Botanical fractions of two rice straw varieties and effects of ammonia trealment. Anim. Prod. 46, 347-352 


\section{STRESZCZENIE}

\section{Określenie rozkładu całej słomy ryżowej przy zastosowaniu celulazy}

Oznaczono rozkład suchej masy całej słomy sześciu odmian ryżu malajskiego, stosując roztwór celulazy przed lub po traktowaniu słomy $4 \%$ roztworem mocznika lub $4 \%$ roztworem wodorotlenku sodu $(\mathrm{NaOH})$.

Dla scharakteryzowania przebiegu rozkładu zastosowano równanie $\mathrm{p}=\mathrm{a}+\mathrm{b}\left(1-\mathrm{e}^{-\mathrm{ct}}\right)$. Tak traktowanie słomy mocznikiem jak i $\mathrm{NaOH}$ istotnie zwiększyło szybko- jak i wolno rozkładalne frakcje. Tempo rozkładu było istotnie obniżone w słomie traktowanej mocznikiem, lecz nie $\mathrm{NaOH}$. Stałe rozkładu nie zależały od agronomicznych i morfologicznych właściwości nietraktowanej słomy. 